Volume 10, Nomor 2, November 2018, pp 170-178 Copyright (C) 2017 Jurnal Akuntansi Maranatha, Program Studi Akuntansi, Fakultas Ekonomi,

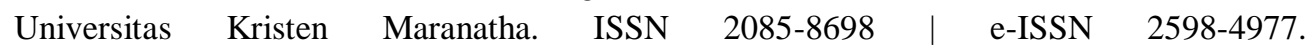
http://journal.maranatha.edu

\title{
Pengaruh Sistem Akuntansi Pemerintah Daerah Terhadap Kualitas Laporan Keuangan Daerah pada Badan Pengelolaan Keuangan Aset Daerah (BPKAD) Pandeglang
}

\author{
Verliani Dasmaran \\ Prodi Akuntansi, Fakultas Ekonomi, Universitas Mathla’ul Anwar Banten \\ eeytea@gmail.com \\ Tri Yulaeli \\ Prodi Akuntansi, Fakultas Ekonomi, Universitas Mathla'ul Anwar Banten \\ Cahyadewi27@gmail.com

\section{Selfiani} \\ Prodi Akuntansi, Fakultas Ekonomi, Universitas Mathla'ul Anwar Banten \\ selfianiselfi@gmail.com
}

\begin{abstract}
The purpose of this study was to determine the effect of the application of the Regional Government Accounting System on the Quality of Financial Reports. The research method used is a summative evaluation method, which is a method that emphasizes the effectiveness of the achievement of programs in the form of certain products, and the results of these studies can provide recommendations for future needs. The population in the study are all parts and sub-sections of the BPKAD Pandeglang Regency, and the sample in this study are employees who understand the Regional Government Accounting System totaling 94 people. The sampling technique uses saturated sampling. Recapitulation results from the overall indicators of the Regional Government Accounting System in BPKAD with a score of 85.63\% indicate that the Regional Government Accounting System has been implemented very well. And the results of the recapitulation of the overall indicators of the Quality of Financial Statements with a score of $87.14 \%$, this indicates that financial management in the Office of Financial and Asset Management of Pandeglang Regency is very good. The results of the study conclude that the Regional Government Accounting System (SAPD) has a positive and significant effect on the Quality of Financial Statements.
\end{abstract}

Keywords: Regional Government Accounting System, Quality of Financial Statements 


\section{Pendahuluan}

Akuntansi pemerintah merupakan bidang ilmu akuntansi yang saat ini sedang berkembang sangat pesat. Melalui otonomi daerah kebijakan pemerintah pusat dalam segelintir bidang diubah menjadi kebijakan daerah termasuk kebijakan dalam pengelolaan keuangan daerah. Dalam sistem akuntansi pemerintahan ditetapkan entitas pelaporan dan entitas akuntansi yang menyelenggarakan sistem akuntansi pemerintah daerah. Tujuan utama adanya perubahan-perubahan kebijakan pengelolaan keuangan adalah untuk mewujudkan tata kelola pemerintahan yang baik dan bersih, berorientasi pada hasil, profesionalitas, proporsionalitas, dan menghasilkan laporan keuangan yang transparan dan akuntabel. Badan Pemeriksaan Keuangan akan memberikan opini Wajar Tanpa Pengecualian kepada Laporan Keuangan Pemerintah Daerah jika Laporan Pemerintah Daerah yang dilaporkan oleh pihak Daerah sudah memenuhi syarat. Atau dapat dikatakan Laporan Keuangan sudah disajikan dan diungkapkan dengan relevan, andal, dapat dipercaya, dan dapat dibandingkan. Badan Pengelolaan Keuangan menemukan beberapa kasus kelemahan sistem pengendalian akuntansi dan Pelaporan Daerah seperti : Pencatatan tidak/belum dilakukan secara akurat, Proses penyusunan laporan tidak sesuai dengan ketentuan, Terlambat penyampaian laporan, Sistem informasi akuntansi dan pelaporan tidak memadai, Sistem informasi akuntansi dan pelaporan belum didukung SDM yang memadai. Perkembangan teknologi dan ekonomi di setiap negara membutuhkan pemerintahan yang baik disebut good governance. Pemerintahan yang baik ini merupakan suatu bentuk keberhasilan dalam menjalankan tugas untuk membangun negara sesuai dengan tujuan yang telah direncanakan (Susilawati \& Dwi Seftihani, 2014). Laporan Keuangan dibuat untuk menyajikan informasi yang relevan, andal dan dapat dipercaya berkenaan dengan posisi keuangan dan seluruh data transaksi yang di catat oleh suatu entitas pelaporan selama satu periode pelaporan. Begitu juga dengan Laporan Keuangan Pemerintah Daerah (LKPD) yang setiap tahunnya mendapat penilaian dari auditor Pemerintah dalam hal ini adalah Badan Pemeriksa Keuangan (BPK) yang berupa opini. Dalam hal ini BPK dapat memberikan 4 macam opini yaitu: Opini Wajar Tanpa Pengecualian (WTP), Opini Wajar Dengan Pengecualian (WDP), Opini Tidak Wajar (TP), dan Pernyataan menolak memberi opini atau tidak memberi pendapat (Disclaimer). Ketika Badan Pemeriksa Keuangan memberikan Opini Wajar Tanpa Pengecualian kepada Laporan Keuangan Pemerintah Daerah ini berarti Laporan Keuangan yang dilaporkan oleh pihak Daerah sudah memenuhi syarat atau dapat dikatakan Laporan Keuangan sudah disajikan dan diungkapkan secara relevan, andal, dapat dipercaya dan dapat dibandingkan.

\section{Kerangka Teoritis dan Hipotesis}

\section{Sistem Informasi Akuntansi}

Menurut James A. Hall (2007; 6), "Sistem adalah kelompok dari dua atau lebih komponen atau subsistem yang saling berhubungan yang berfungsi dengan tujuan yang sama." Sistem diartikan sebagai komponen-komponen yang saling bekerja sama dalam mencapai suatu tujuan. Sistem disebut subsistem ketika dipandang hubungannya dengan sistem yang lebih besar di mana sistem tersebut hanya menjadi bagian dari sistem yang lebih besar. Sedangkan subsistem disebut sistem ketika menjadi fokus perhatian.

Sistem akuntansi adalah organisasi formulir, catatan dan laporan yang dikoordinasi sedemikian rupa untuk menyediakan informasi keuangan yang dibutuhkan oleh manajemen guna 
memudahkan pengelolaan perusahaan. Akuntansi adalah suatu sistem. Sistem adalah suatu kesatuan yang terdiri atas subsistem-subsistem atau kesatuan yang lebih kecil, yang berhubungan satu sama lain dan mempunyai tujuan tertentu. Suatu sistem mengolah input (masukan) menjadi output (keluaran). Input sistem akuntansi adalah bukti-bukti transaksi dalam bentuk dokumen atau formulir. Outputnya adalah laporan keuangan. Dalam proses akuntansi, terdapat beberapa catatan yang dibuat. Catatan-catatan tersebut adalah jurnal, buku besar, dan buku pembantu (Eliana, 2017).

Sistem Informasi Akuntansi adalah sebuah sistem informasi yang menangani segala sesuatu yang berkenaan dengan akuntansi. Sistem informasi akuntansi adalah suatu sistem dalam sebuah organisasi yang bertanggung jawab untuk penyiapan informasi yang diperoleh dari pengumpulan dan pengolahan data transaksi yang berguna bagi semua pemakai baik di dalam maupun di luar perusahaan. Sistem Informasi Akuntansi juga dapat diartikan sebagai kumpulan kegiata-kegiatan dari organisasi yang bertanggung jawab untuk menyediakan informasi keuangan dan informasi yang didapatkan dari transaksi data untuk tujuan pelaporan internal maupun eksternal perusahaan, maka dari itu sangat perlu mengontrol semua arus dana agar penggunaannya bisa efektif. Subsistem SIA memproses berbagai transaksi keuangan dan transakasi non keuangan yang secara langsung mempengaruhi pemrosesan transaksi keuangan. Menurut James A. Hall (2007; h:10), ada tiga subsistem SIA, yaitu: 1. Sistem pemrosesan transaksi (Transaction Processing System) Yang mendukung operasi bisnis harian melalui berbagai dokumen serta pesan untuk para pengguna diseluruh perusahaan. 2. Sistem buku besar/Pelaporan keuangan (General Ledger/Financial Reporting System) Yang menghasilkan laporan keuangan, seperti neraca, arus kas, serta berbagai laporan lainnya yang disyaratkan oleh hukum. 3. Sistem pelaporan manajemen (Management Reporting System). Yang menyediakan pihak manajemen internal berbagai laporan keuangan bertujuan khusus serta informasi yang dibutuhkan dalam pengambilan keputusan, seperti anggaran, laporan kinerja, serta laporan pertanggungjawaban.

Sistem akuntansi keuangan daerah (SAKD) adalah suatu sistem akuntansi yang meliputi proses pencatatan, penggolongan, penafsiran, peringkasan transaksi atas kejadian keuangan serta pelaporan keuangannya dalam rangka pelaksanaan APBD, dilaksanakan sesuai dengan prinsipprinsip akuntansi, sebagaimana yang dinyatakan dalam Kepmendagri No. 29 Tahun 2002. Sedangkan dalam permendagri No. 13 Tahun 2006 diungkapkan bahwa sistem akuntasi keuangan daerah meliputi serangkaian prosedur mulai dari proses pengumpulan data, pencatatan, pengikhtisaran, sampai dengan pelaporan keuangan dalam rangka pertanggung jawaban pelaksanaan APBD yang dapat dilakukan secara manual atau menggunakan aplikasi komputer. Sistem akuntansi yang lemah menyebabkan laporan keuangan yang dihasilkan juga kurang handal dan kurang relevan untuk pembuatan keputusan (Mardiasmo, 2004:56).

Menurut Halim (2007:43) definisi dari akuntansi keuangan daerah adalah proses pengidentifikasian, pengukuran, pencatatan, dan pelaporan transaksi ekonomi (keuangan) dari entitas pemerintah daerah (kabupaten, kota, atau provinsi) yang dijadikan sebagai informasi dalam rangka pengambilan keputusan ekonomi yang diperlukan oleh pihak-pihak eksternal entitas pemerintah daerah (kabupaten, kota, atau provinsi). Sedangkan, menurut Rasdianto (2013:6) sistem akuntansi keuangan daerah adalah sistem akuntansi yang meliputi proses pencatatan, penggolongan, penafsiran, peringkasan transaksi atau kejadian keuangan serta pelaporan keuangan dalam rangka pelaksanaan anggaran pendapatan belanja daerah (APBD). Dari pengertian tersebut 
dapat ditarik kesimpulan bahwa sistem akuntansi keuangan daerah merupakan serangkaian prosedur yang saling berhubungan yang disusun sesuai dengan suatu skema yang menyeluruh yang ditinjau untuk menghasilkan informasi dalam bentuk laporan keuangan yang akan digunakan oleh pihak intern dan pihak ekstern pemerintah daerah untuk mengambil keputusan ekonomi.

Standar Akuntansi Pemerintahan menurut Bastian (2010) adalah prinsip-prinsip akuntansi yang diterapkan dalam menyusun dan menyajikan laporan keuangan pemerintah. Dengan demikian SAP merupakan persyaratan yang mempunyai kekuatan hukum dalam upaya meningkatkan kualitas laporan keuangan pemerintah di Indonesia. Standar akuntansi digunakan oleh akuntan keuangan di pemerintahan sebagai pedoman dalam penyusunan dan penyajian laporan keuangan pemerintahan (Susilawati dan Riana, 2014).

Menurut Agoes (2012) pemeriksaan laporan keuangan akan menghasilkan kualitas laporan keuangan yang menghasilkan opini dari pernyataan profesioal pemeriksa mengenai kewajaran informasi dari laporan keuagan. Karakteristik kualitas laporan keuangan menurut Undang-Undang No. 71 tahun 2010 tentang Standar Akuntansi Keuangan, antara lain sebagai berikut:

1) Relevan

Laporan keuangan bisa dikatakan relevan apabila informasi yang termuat di dalamnya dapat mempengaruhi keputusan pengguna dengan membantu mereka mengevaluasi peristiwa masa lalu atau masa kini, dan memprediksi masa depan, serta menegaskan atau mengoreksi hasil evaluasi mereka di masa lalu. Informasi yang relevan memiliki karakteristik : memberikan manfaat umpan balik (feedback value) ; memberikan manfaat prediktif (predictive value) ; disajikan tepat waktu (timeliness).
2) Andal (Reliability)

Informasi dalam laporan keuangan bebas dari pengertian yang menyesatkan dan kesalahan material, menyajikan setiap fakta secara jujur, serta dapat diverifikasi. Informasi mungkin relevan, tetapi jika hakikat atau penyajiannya tidak dapat diandalkan maka penggunaan informasi tersebut secara potensial dapat menyesatkan. Informasi yang andal memenuhi karakteristik : penyajian jujur (faithfulness of presentation); dapat diverifikasi (verifiability); netralitas.

3) Dapat dibandingkan

Informasi yang termuat dalam laporan akan lebih berguna jika dapat dibandingkan dengan laporan keuangan periode sebelumnya atau laporan keuangan entitas pelaporan lain umumnya.

4) Dapat dipahami

Informasi yang disajikan dalam laporan keuangan dapat dipahami oleh pengguna dan dinyatakan dalam bentuk serta istilah yang disesuaikan dengan batas pemahaman para pengguna.

Harus disadari bahwa terdapat banyak pihak yang akan mengandalkan informasi laporan keuangan yang disusun oleh pemerintah sebagai dasar untuk pengambilan keputusan. Oleh karena itu informasi dalam laporan keuangan harus berkualitas, informasi dalam laporan keuangan yang akan dipublikasikan tersebut harus disajikan secara wajar terbebas dari salah saji yang material sehingga tidak menyesatkan para penggunanya, laporan keuangan hanya akan bermanfaat jika laporan keuangan yang diinformasikan disajikan dengan valid dan dapat diandalkan. Jika laporan keuangan yang dipublikasikan buruk, artinya laporan keuangan tersebut dihasilkan dari sistem akuntansi yang buruk sehingga didalamnya mengandung kesalahan yang material dalam penyajian, tidak disusun sesuai dengan standar pelaporan, dan tidak tepat waktu dalam penyampainnya maka hal itu akan berdampak buruk bagi para pengguna 
laporan dan pihak penyaji laporan itu sendiri, (Mahmudi, 2013: 9).

\section{Metode Penelitian}

Penulis mengambil metode penelitian evaluasi sumatif, metode evaluasi sumatif adalah menekankan pada efektivitas pencapaian program yang berupa produk tertentu. Sedangkan, penelitian menurut tingkat eksplanasinya, penulis mengambil penelitian asosiatif/hubungan. Penelitian asosiatif merupakan penelitian yang bertujuan untuk mengetahui hubungan antara dua variabel atau lebih. Populasi dalam penelitian ini adalah semua bagian dan sub-bagian pada Dinas Pengelolaan Keuangan dan Aset di Kabupaten Pandeglang sebanyak 94 orang pegawai. Sedangkan, sampel dalam penelitian ini menggunakan teknik sampling jenuh untuk menentukan sampel, karena Laporan Keuangan Pemerintah Daerah terdiri dari beberapa Satuan Kerja Perangkat Daerah (SKPD) untuk mempermudah penulis dalam penelitian terhadap penerapan Sistem Akuntansi Pemerintah Daerah maka dari itu penulis mengambil sempel dari Dinas Pengelolaan Keuangan dan Aset (DPKA) yang merupakan salah satu dari Satuan Kerja Perangkat Daerah yang sekaligus sebagsi SKPKD (Satuan Kerja Pengelolaan Keuangan Daerah). Sampling jenuh adalah teknik penentuan sampel bila semua anggota populasi digunakan sebagai sampel. Sampel penelitian ini adalah pegawai yang memahami Sistem Akuntansi Keuangan Daerah yang berjumlah 94 orang pegawai pada Dinas Pengelolaan Keuangan dan Aset di Kabupaten Pandeglang. Penyusunan kuesioner menggunakan teknik skala Likert dengan angka 5 adalah sangat baik dan 1 adalah tidak baik. Penyebaran kuisioner kepada 94 responden yang terdiri dari 20 item pernyataan untuk variable $X$ dan 20 item pernyataan untuk variabel $\mathrm{Y}$. Variabel bebas dalam penelitian ini adalah Sistem Akuntansi Pemerintah dan variabel terikat dalam penelitian ini adalah Kualitas Laporan Keuangan. Penelitian ini menggunakan aplikasi SPSS 24.

\section{Hasil Penelitian dan Pembahasan}

Tabel 1

Profil Responden

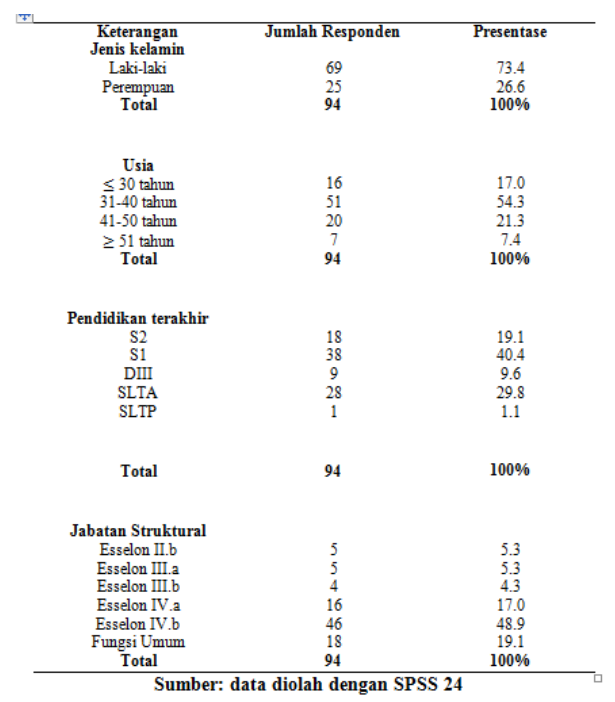

Data yang diperoleh melalui kuesioner yang di isi oleh responden menunjukan bahwa responden yang berjenis kelamin laki-laki sebesar $73 \%$, dan responden yang berjenis kelamin perempuan sebesar $27 \%$ jadi dapat disimpulkan mayoritas responden dalam penelitian ini adalah laki-laki. Responden yang berusia $<30$ tahun berjumlah 16 orang atau sebesar 17\%, 31-40 tahun berjumlah 51 orang atau sebesar 55\%, 41-50 tahun berjumlah 20 orang atau sebesar $22 \%,>50$ tahun berjumlah 6 orang atau sebesar $6 \%$. Jadi dapat disimpulkan bahwa mayoritas responden dalam penelitian ini berusia 31-40 tahun. Responden berdasarkan pendidikan lulusan S2 berjumlah 18 orang atau sebesar $19 \%$, lulusan S1 berjumlah 38 orang atau sebesar $40 \%$, lulusan DIII berjumlah 9 orang atau sebesar $10 \%$, lulusan SLTA berjumlah 28 orang atau 
sebesar 30\%, lulusan SLTP berjumlah 1 orang atau sebesar 1\%. Jadi dapat disimpulkan bahwa responden yang berdasarkan pendidikan terakhir dalam penelitian ini mayoritas $\mathrm{S} 1$.

Berdasarkan uji validitas seluruh indikator yang membentuk variabel dinyatakan valid karena nilai signifikan lebih kecil dari 0,05 dan uji reliabilitas dari variabel-variabel yang diteliti dinyatakan reliabel karena nilai Cronbach Alpha lebih besar dari 0,6 (data terlampir).

Selain dilakukan uji validitas dan reliabilitas maka dilakukan uji asumsi klasik. Berikut disajikan hasil dari uji asumsi klasik yang dilakukan pada penelitian ini:

Tabel 2

Uji Asumsi Klasik

\begin{tabular}{|c|c|c}
\hline Nama Uji & $\begin{array}{c}\text { Nilai } \\
\text { Standar } \\
\text { Uji }\end{array}$ & Keterangan \\
\hline Normalitas & $\begin{array}{c}\text { Nilai sig. } \\
>0.05\end{array}$ & $\begin{array}{c}\text { Data berdistribusi } \\
\text { normal }\end{array}$ \\
\hline Multikolinearitas & $\begin{array}{c}\text { Nilai } \\
\text { Tolerance } \\
>0.1\end{array}$ & $\begin{array}{c}\text { Tidak terjadi } \\
\text { multikolinearitas }\end{array}$ \\
& $\begin{array}{c}\text { Nilai VIF } \\
<10\end{array}$ & \\
\hline Heteroskedastisitas & $\begin{array}{c}\text { Nilai sig. } \\
>0.05\end{array}$ & $\begin{array}{c}\text { Tidak terjadi } \\
\text { heteroskedastisitas }\end{array}$ \\
\hline Autokorelasi & $\begin{array}{c}\text { dU }<\text { DW } \\
<4-d U\end{array}$ & $\begin{array}{c}\text { Tidak terjadi } \\
\text { autokorelasi }\end{array}$ \\
\hline
\end{tabular}

Sumber: data diolah dengan SPSS 24

\section{(lampiran)}

Berdasarkan tabel 2, menunjukkan bahwa data berdistribusi normal, tidak terjadi multikolinearitas, tidak terjadi heteroskedastisitas dan tidak terjadi autokorelasi sehingga data lulus uji asumsi klasik dan dapat dilakukan uji selanjutnya.
Tabel 3

\section{Koefisien Korelasi Dan Tafsirannya}

\begin{tabular}{|c|c|}
\hline Imterval Korelasi & Tingkat hubungan \\
\hline $0,00-0,199$ & Sangat Rendah \\
$0,20-0,399$ & Rendah \\
$0,40-0,599$ & Sedang \\
$0,60-0,799$ & Kuat \\
$0,80-1,000$ & Sangat Kuat \\
\hline
\end{tabular}

Sumber : Sugiyono $(2014: 184)$

Tabel 4

Uji Korelasi

Correlations

\begin{tabular}{l|l} 
Sistem & Kualitas
\end{tabular}

Akuntansi Laporan

Pemerintah Keuangan

$\begin{array}{ll}\text { Sistem } & \text { Pearson } \\ \text { Akuntansi } & \text { Correlation }\end{array}$

Pemerintah Sig. (2-

tailed)

\begin{tabular}{rlrr} 
& $\mathrm{N}$ & 94 & 94 \\
\hline Kualitas & Pearson & $.974^{* *}$ & 1
\end{tabular}

Laporan Correlation

Keuangan Sig. (2- $\quad .000$ tailed) $\mathrm{N}$

94

94

**. Correlation is significant at the 0.01 level (2tailed).

\section{Sumber: data diolah dengan SPSS 24}

Berdasarkan tabel 3, dapat dilihat bahwa korelasi variabel sistem akuntansi pemerintah memiliki nilai korelasi sebesar 0,974. Dari hasil perhitungan diatas dapat diketahui bahwa terdapat hubungan yang positif sangat kuat antara Sistem Akuntansi Pemerintah dengan Kualitas Laporan Keuangan sebesar 0,974 berada pada posisi $0,80-1,000$ untuk lebih jelas bisa dilihat pada tabel 3 . 


\begin{abstract}
Tabel 5
Koefisien Determinasi Model Summary ${ }^{b}$

\begin{tabular}{|c|c|c|c|c|c|}
\hline Model & $\mathrm{R}$ & $\begin{array}{c}\mathrm{R} \\
\text { Square }\end{array}$ & $\begin{array}{c}\text { Adjusted } \\
\text { R } \\
\text { Square }\end{array}$ & $\begin{array}{c}\text { Std. } \\
\text { Error of } \\
\text { the } \\
\text { Estimate }\end{array}$ & $\begin{array}{l}\text { Durbin- } \\
\text { Watson }\end{array}$ \\
\hline 1 & $.974^{\mathrm{a}}$ & .948 & .948 & .10616 & \\
\hline
\end{tabular}

a. Predictors: (Constant), Sistem Akuntansi

Pemerintah

b. Dependent Variable: Kualitas Laporan Keuangan

\section{Sumber: data diolah dengan SPSS 24}

Dari perhitungan tersebut dapat dilihat seberapa besar kontribusi antara variabel $\mathrm{X}$ (sistem akuntansi pemerintah) terhadap Variabel Y (kualitas laporan keuangan) yaitu sebesar $94,8 \%$ dan sisanya $6,2 \%$ dipengaruhi oleh faktor lain diluar penelitian ini. Di antaranya faktor ekspektasi kinerja, faktor sistem informasi, faktor sistem keuangan, faktor efektivitas kinerja.
\end{abstract}

\section{Tabel 6 \\ Uji Parsial}

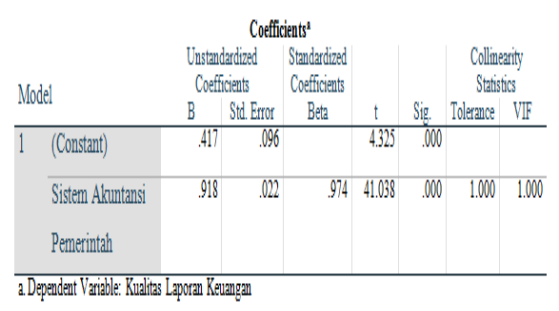

Sumber: data diolah dengan SPSS 24

Berdasarkan rumus tersebut, maka rumus regresi penelitian ini adalah sebagai berikut:

Kualitas Laporan Keuangan = 0,417 + 0,918 Sistem Akuntansi Pemerintah

Berdasarkan persamaan regresi linier berganda tersebut, dapat dijelaskan sebagai berikut:

$\mathrm{b}_{0}=$ Jika variabel sistem akuntansi pemerintahsama dengan nol maka variabel kualitas laporan keuangan adalah sebesar 0,417 .

$\mathrm{b}_{1}=$ variabel sistem akuntansi pemerintah miliki koefisien positif sebesar 0,918 (satu) satuan variabel sistem akuntansi pemerintah akan meningkatkan kualitas laporan keuangansebesar 0,918.

Untuk menguji hipotesis dapat dilihat dari nilai signifikan dari variabel sistem akuntansi pemerintah adalah sebesar 0,000 , nilai signifikan ini lebih kecil dari $0,05(0,000<0,05)$. Hasil penelitian ini menunjukkan bahwa sistem akuntansi pemerintah berpengaruh signifikan terhadap kualitas laporan keuangan. Pengaruh yang ditunjukkan variabel sistem akuntansi pemerintah adalah sebesar 0,918 . Nilai ini menunjukkan bahwa semakin besar pengaruh sistem akuntansi pemerintah, maka akan semakin meningkat kualitas laporan keuangan.

Hasil ini menunjukkan bahwa dengan adanya reformasi atau pembaharuan didalam sistem pertanggung jawaban keuangan daerah, sistem lama yang selama ini digunakan oleh pemerintah daerah baik pemerintah provinsi maupun pemerintah kabupaten/kota sudah tidak dapat lagi mendukung kebutuhan pemerintah daerah untuk menghasilkan laporan keuangan yang efektif dan efisien, maka untuk dapat menghasilkan laporan keuangan tersebut diperlukan suatu Sistem Akuntansi Pemerintah Daerah yang didasarkan atas Standar Akuntansi Pemerintah. Diharapkan pemerintah daerah mampu menghasilkan laporan pertanggung jawaban keuangan yang lebih transparan dan akuntabel.

Kondisi yang diharapkan mengharuskan adanya suatu pengembangan sistem akuntansi yang baru, yaitu direkomendasikannya accrual basic (basis akrual), yaitu dengan mengembangkan prinsip dan asumsi bahwa pencatatan 
transaksi keuangan bukan hanya pada saat terjadi penerimaan uang atau dilakukan pembayaran saja. Dengan basis akrual akan memberikan informasi kepada pemakai tidak hanya transaksi masa lalu yang melibatkan penerimaan dan pengeluaran kas tetapi kewajiban kas di masa depan, serta mempresentasikan kas yang akan diterima di masa depan.

Menurut Permendagri Nomor 64 Tahun 2013 Sistem Akuntansi Pemerintah Daerah yang selanjutnya disingkat SAPD adalah rangkaian sistematik dari prosedur, penyelenggara, peralatan dan elemen lain untuk mewujudkan fungsi akuntansi sejak analisis transaksi sampai dengan pelaporan keuangan di lingkungan organisasi pemerintahan daerah. Sistem akuntansi pemerintahan daerah secara garis besar terdiri atas 4 (empat) prosedur akuntansi, yaitu:

1. Prosedur Akuntansi Pendapatan

2. Prosedur Akuntansi Belanja

3. Prosedur Akuntansi Aset

4. Prosedur Selain Kas

Laporan keuangan merupakan media bagi sebuah entitas, dalam hal ini untuk mempertanggungjawabkan kinerja keuangannya kepada publik pemerintah harus mampu menyajikan laporan keuangan yang mengandung informasi keuangan yang berkualitas Dalam Standar Akuntansi Pemerintah (SAP) yang dijelaskan bahwa laporan keuangan berkualitas itu memenuhi karakteristik diantaranya yaitu relevan, andal, dapat dibandingkan, dan dapat dipahami (Peraturan Pemeritah No.71 Tahun 2010).

\section{Simpulan dan Saran}

Berdasarkan hasil penelitian menunjukkan bahwa terdapat hubungan yang positif sangat kuat antara Sistem Akuntansi Pemerintah dengan Kualitas Laporan Keuangan sebesar 0,974. Sistem Akuntansi Keuangan Daerah terhadap Kualitas Laporan Keuangan Daerah memiliki hubungan sangat kuat dan memiliki arah yang positif yang berarti apabila sistem akuntansi keuangan daerah baik maka kualitas laporan keuangan daerah juga akan semakin baik, Sehingga dapat disimpulkan bahwa terdapat pengaruh antara Sistem Akuntansi Keuangan Daerah dengan Kualitas Laporan Keuangan Daerah, dan menunjukkan bahwa jika Sistem Akuntansi Keuangan Daerah semakin baik maka akan diikuti dengan Kualitas Laporan Keuangan Daerah yang baik pula.Dilihat seberapa besar kontribusi antara variabel $\mathrm{X}$ (sistem akuntansi pemerintah) terhadap Variabel Y (kualitas laporan keuangan) yaitu sebesar $94,8 \%$ dan sisanya $6,2 \%$ dipengaruhi oleh faktor lain diluar penelitian ini. Di antaranya faktor ekspektasi kinerja, faktor sistem informasi, faktor sistem keuangan, faktor efektivitas kinerja. Hasil menunjukkan bahwa secara parsial, sistem akuntansi pemerintah berpengaruh positif terhadap kualitas laporan keuangan. Hal ini menjelaskan bahwa dengan penerapan sistem akuntansi daerah yang baik dapat meningkatkan kualitas laporan keuangan pemerintah daerah.

Berdasarkan

kesimpulan penelitian, maka saran yang diberikan bagi penelitian ini adalah penelitian ini diharapkan dapat menambah informasi ilmu pengetahuan dan pemahaman yang berkaitan dengan sistem keuangan daerah dan pengaruhnya terhadap kualitas laporan keuangan daerah dan juga sebagai masukan serta tambahan referensi bagi pembaca. Untuk penelitian selanjutnya, diharapkan dapat meneliti dengan menggunakan variabel lainnya yang tidak diteliti dalam penelitian ini dan disarankan untuk menggunakan populasi dan sampel yang berbeda agar diperoleh kesimpulan yang mendukung teori dan konsep yang dapat diterima secara umum. 


\section{Daftar Pustaka}

Agoes, Sukrisno, 2012,“Auditing Pemeriksaan Oleh Kantor Akuntan Publik", Jilid satu. Jakarta: Lembaga Penerbit Fakultas Ekonomi Universitas Indonesia

Bastian, Indra, 2010,“Akuntansi Sektor Suatu Pengantar", Edisi Ketiga. Jakarta: Erlangga

Eliana, 2017, "Pengaruh Penerapan Sistem Akuntansi Keuangan Pemerintah Daerah Terhadap Kualitas Laporan Keuangan Pemerintah Daerah (Studi Pada Dinas Pendidikan Provinsi Aceh). SI-MEN (Akuntansi dan Manajemen) STIES Vol. 8 No 1 Juni 2017

Halim, Abdul, 2007,"Akuntansi Sektor Publik Akuntansi keuangan daerah", Edisi Revisi, Jakarta, Salemba Empat

James, A. Hall, 2007, "Sistem Informasi Akuntansi”. Edisi Ketiga, Terjemahan Amir Abadi Yusuf, Salemba Empat, Jakarta

Konsep dan Siklus Akuntansi di Pemerintah Daerah http://keuda.kemendagri.go.id/pages/ view/20-modul-penerapanakuntansiberbasis-akrual

Mahmudi, 2013, "Manajemen Kinerja Sektor Publik". Sekolah Tinggi IlmuManajemen YKPN, Yogyakarta.

Mardiasmo, 2004,"Membangun Akuntabilitas Publik Keuangan Negara" Media Akuntansi 39/April/Tahun Xi/2004, Hal 12.

Rasdianto, Erlina, 2013, “Akuntansi Keuangan Daerah Berbasis Akrual”, Medan: Brama Ardian

Republik Indonesia, 2010, "Peraturan Pemerintah Nomor 71 Tahun 2010 tentang Standar Akuntansi Pemerintahan".

Sugiyono, 2014,"Metode Penelitian Kunatitatif Kualitatif dan R\&D", Bandung Alfabeta
Susilowati, Dwi Seftihani Riana, 2014, "Standar Akuntansi Pemerintah dan Sistem Pengendalian Intern Sebagai Anteseden Kualitas Laporan Keuangan Pemerintah Daerah", Study \& Accounting Research, Volume XI, No.1 - 2014 